\title{
プロピレングリコールを用いるセロトニンの 簡便かつ高感度な蛍光光度法
}

加藤 貴大 ${ }^{1}$, 時 吉 愛 $^{1}$, 柏田 侑亮 ${ }^{1}$, 宮地加奈子 ${ }^{2}$, 森山 健三 ${ }^{2}$,

森本 茂文 ${ }^{3}$, 浅野麻実子 ${ }^{1}$, 山口 敬子 ${ }^{\circledR 1}$, 藤田 芳一 $^{1}$

1 緒言

セロトニン（5-ヒドロキシトリプタミン，5-HT）は，人 体内に $10 \mathrm{mg}$ 存在し, $90 \%$ は小腸粘膜のクロム親和細胞, $8 \%$ が血小板, $2 \%$ が中枢神経系に存在している. 5-HT は, 血液凝固・血管収縮, 疼痛閾值の調節, 脳血管収縮活 動の調節, 睡眠, 体温, 情緒・気分, 食欲, 㗐吐, 性機能 など多くの末梢・中枢作用を示し, 血槳中のセロトニン量 が異常を示す疾患として, ダンピング症候群 ${ }^{122}$, カルチノ イド腫瘍 ${ }^{3)}$ ，喘息及び偏頭痛などとの関連性が注目されて おり, 呼吸, 歩行, 咀噮などのリズム運動によって賦活さ れる ${ }^{4)}$, 非常に重要な生理活性アミンである.

5-HT は，必須アミノ酸であるトリプトファンから 5-七 ドロキシトリプトファンを経て生合成され，5-ヒドロキシ

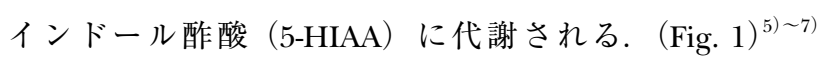
5-HIAA は脳内の 5-HT 代謝産物のほほ $100 \%$ を占め, 5-HT の貯蔵と代謝が行われる脳㧍よび末梢部位から，尿 中に排泄される，健常成人における通常の尿中の 5-HIAA 量は, 1 日 2 $10 \mathrm{mg}$ であり, それらの量を非侵襲性であ る簡便な尿検查などで簡便に測定することは, 疾病の診断 及び治療予後のモニタリングを行う上でも大変有意義であ る.

従来，5-HT の測定法としては，フルオレサミンや $o_{-}$フ タルアルデヒド，2,3-ナフトジアルデヒドなどのラベル化 試薬を用いたアミノ基の蛍光誘導体化, ベンジルアミンと 5-ヒドロキシインドール化合物の蛍光反応を利用する方法 など多くの定量法が報告されているが, ラベル化試薬は多 くのアミン類を誘導体化し, ベンジルアミンは他の生理活 性アミンとも反応するなど, 選択性や簡便性において問題 を抱えている ${ }^{899)}$.

今回, 5-HT をプロピレングリコールなどの溶媒中で加 熱するとき, 蛍光極大波長が顕著にレッドシフトする発蛍

${ }^{1}$ 大阪薬科大学：569-1094 大阪府高槻市奈佐原 4-20-1

2 近畿大学医学部附属病院薬剂部 : 589-8511 大阪府大阪狭山市 大野東 $377-2$

3 独立行政法人国立病院機構大阪南医療センター薬郕科 : 586 8521 大阪府河内長野市木戸東町 2-1
光体が生成することを見いだしたので，本反応を用いて， 簡便で選択的な 5-HT の蛍光光度定量法の開発を目的とし, 加熱温度と時間, 反応溶媒などの基礎的定量条件, および 他の生理活性アミンの反応性などについて種々検討を行っ た.

\section{2 実験}

\section{$2 \cdot 1$ 試薬の調製}

セロトニン溶液：5-Hydroxytryptamine（5-HT，和光純 薬製) $25 \mathrm{mg}$ を精密に測り, メタノールを加えて溶解させ た後，プロピレングリコールで希釈してセロトニン溶液を 調製し, 冷所保存した。

なお，プロピレングリコールは和光純薬製をそのまま用 い,メタノールはナカライテスク製をモレキュラーシーブ （キシダ化学製）にて脱水後用いた.

\section{$2 \cdot 2$ 装 置}

蛍光スペクトル及び蛍光強度の測定：日立製 F-2500 形 分光蛍光光度計を用い, セルは層長 $10 \mathrm{~mm}$ の四面透明石 英製セルを使用した。

また，加熱操作にはタイテック製アルミブロックドライ サーモユニットDTU-1C を用いた.

\section{$2 \cdot 3$ 標準定量操作}

共栓試験管にセロトニン $0.05 \sim 2.5 \mu \mathrm{g} / \mathrm{mL}$ のプロピレ ングリコール溶液 $2.0 \mathrm{~mL}$ を加え, よく擋捧する. 次に共 栓試験管に空冷管を付し，アルミブロック恒温槽中で, $170{ }^{\circ} \mathrm{C}, 40$ 分加熱, 5 分水冷した後, 一定量のエタノール で空泠管をよく洗浄し，洗液とともに全量 $6.0 \mathrm{~mL}$ の試料 溶液とする．次に本溶液（Sample）と同様に処理して得た 空試験液（Blank）の相対蛍光強度（RFI）をそれぞれ励起 波長 $(\mathrm{Ex}) 474 \mathrm{~nm}$, 蛍光波長 $(\mathrm{Em}) 550 \mathrm{~nm}$ で測定した值 の差 $(\Delta F)$ を求め, あらかじめ作成して得た検量線により セロトニン量を求める. 


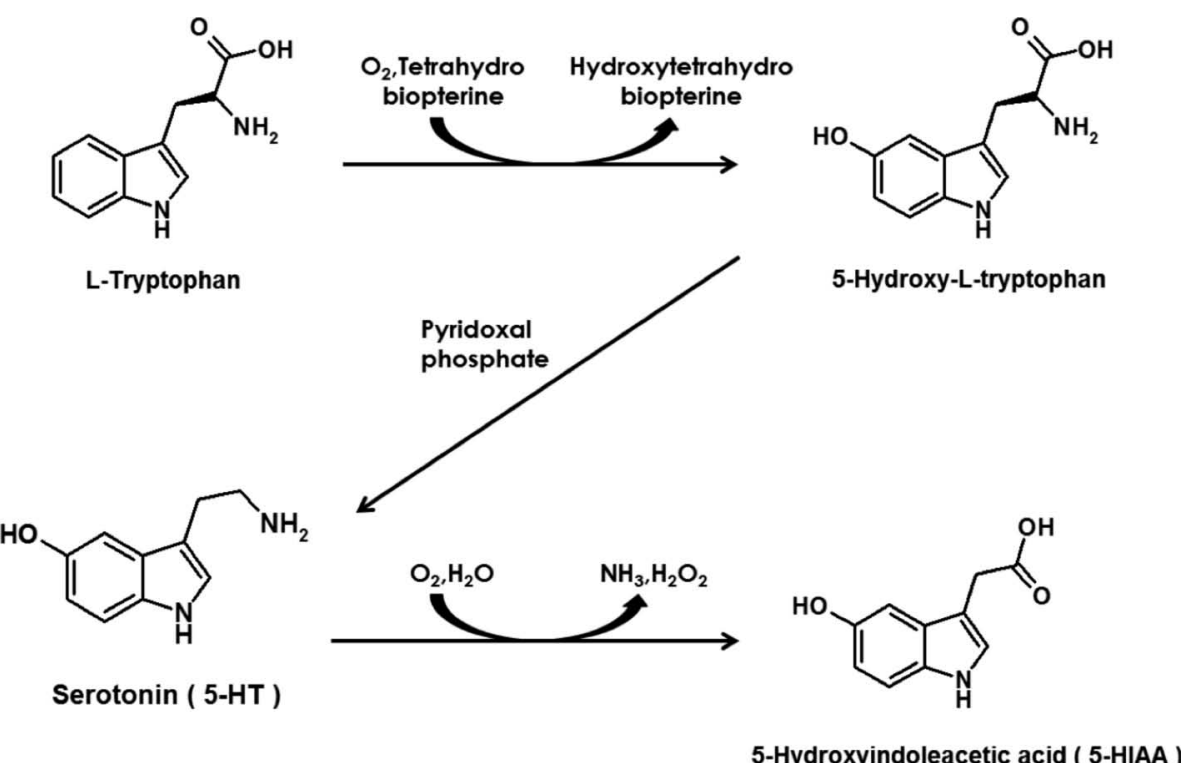

Fig. 1 The metabolism of 5-HT

Table 1 Effect of reaction solvents

\begin{tabular}{lccr}
\hline \multirow{2}{*}{ Reaction solvents } & \multicolumn{2}{c}{ RFI $^{\text {a) }}$} & \multirow{2}{*}{$\Delta F$} \\
\cline { 2 - 3 } & Sample (S) & Blank (B) & \\
\hline Propylene glycol & 114.7 & 0.1 & 114.6 \\
1,3-Propanediol & 81.5 & 0.3 & 81.2 \\
Polyethylene glycol 400 & 6.4 & 1.3 & 5.1 \\
Polyethylene glycol 300 & 7.3 & 1.6 & 5.7 \\
Polyethylene glycol 200 & 6.2 & 1.2 & 5.0 \\
Diethylene glycol & 78.3 & 0.3 & 78.0 \\
Ethylene glycol & 47.4 & 0.3 & 47.1 \\
Dimethyl sulfoxide & 6.5 & 0.1 & 6.4 \\
Ethanol & 1.3 & 0.1 & 1.2 \\
Methanol & 2.9 & 0.0 & 2.9 \\
$\mathrm{H}_{2} \mathrm{O}$ & 0.2 & 0.1 & 0.1 \\
\hline
\end{tabular}

a) RFI (Relative fluorescenece intensity). $5-\mathrm{HT}: 1.0 \mu \mathrm{g} / \mathrm{mL}$, Ex 474 nm, Em 550 nm

3 結果と考察

\section{$3 \cdot 1$ 反応溶媒の選定}

本発蛍光体生成時における反応溶媒の影響を, メ夕ノー ル, エタノール, ジメチルスルホキシド, エチレングリ コール, ジエチレングリコール, ポリエチレングリコール, 1,3-プロパンジオール，1,2-プロパンジオール（以下プロピ レングリコールとする) など, 種々の溶媒について検討し た. その結果 Table 1 に示すように, プロピレングリコー ルを用いるとき, 最大で一定の $\Delta F$ を示した. Fig. 2 に検討 した溶媒の構造を示す。

\section{$3 \cdot 2$ 反応温度と反応時間の影響}

本発蛍光体生成時における反応温度の影響を, 150 , 160, $170,180{ }^{\circ} \mathrm{C}$ で, 更に反応時間の影響を 15 ～ 90 分の 範囲で検討した。 その結果, 発蛍光体は $170{ }^{\circ} \mathrm{C} て ゙ 40$ 分間

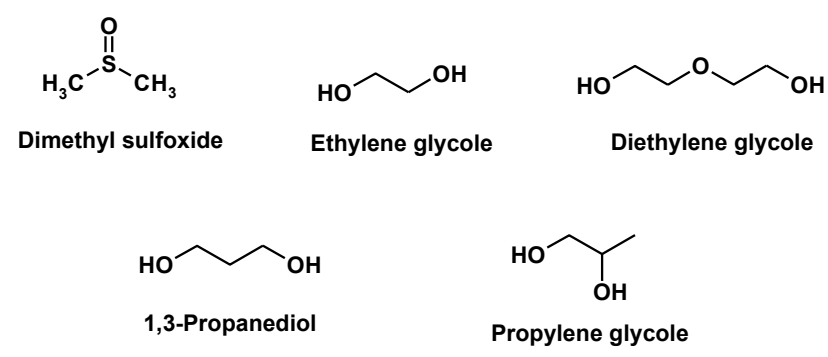

Fig. 2 Structure of reaction solvents used

加熱したときに最大で一定の $\Delta F$ を示し, 室温静置 180 分

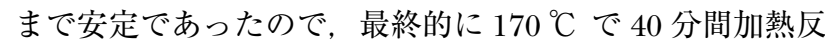
応させることにした.

\section{$3 \cdot 3$ 反応溶媒量及び測定溶媒量の影響}

蛍光体生成反応時, 反応溶媒量の影響を, $1.0,2.0,3.0$ $\mathrm{mL}$ で検討したところ，1.0 mLのときには蛍光強度は低 かったが，2.0，3.0 mLのときにはあまり大きな差は見ら れなかったので, 操作の簡便性からも最終的に反応溶媒量 を $2.0 \mathrm{~mL}$ にすることにした．次に生成した蛍光体の溶解 剂として, 最も溶解性に優れているエタノールの量を, 4.0, 6.0, 8.0, $10.0 \mathrm{~mL}$ で検討したところ, $6.0 \mathrm{~mL}$ のとき に最大で一定の $\Delta F$ を示したので, 測定溶媒量も考慮して, 最終的にエタノールを加え全量で $6.0 \mathrm{~mL}$ にすることにし た.

\section{$3 \cdot 4$ 蛍光スペクトル}

以上の基礎的定量条件の検討結果に基づき，発蛍光体の 蛍光スペクトルを測定したところ, Fig. 3 に示すように, $474 \mathrm{~nm}$ で励起するとき, Sample 溶液と Blank 溶液との間 


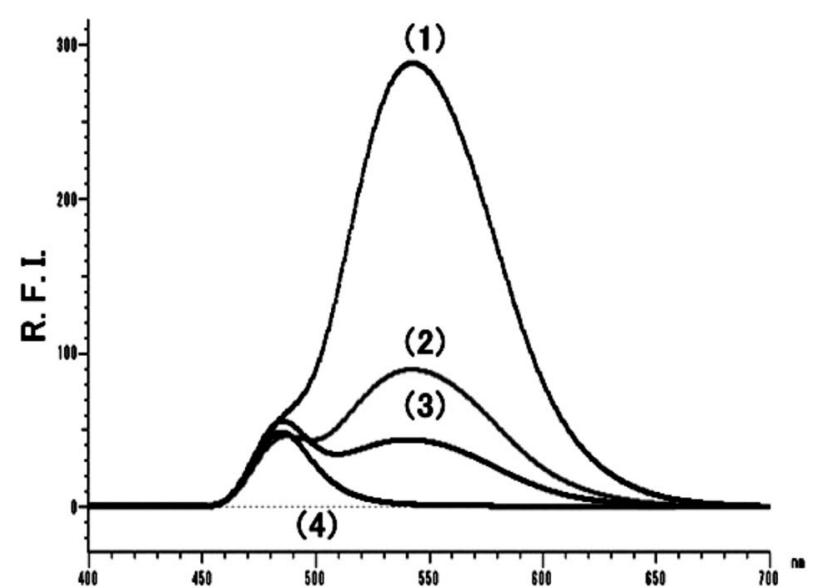

Fig. 3 Fluorescence emission spectra (uncorrected) Curves (1) (3); serotonin, (1) $2.81 \mu \mathrm{g} / \mathrm{mL}$, (2) 0.82 $\mu \mathrm{g} / \mathrm{mL}$, (3) $0.41 \mu \mathrm{g} / \mathrm{mL}$, Curve (4); reagent blank Ex $474 \mathrm{~nm}$

に明瞭な蛍光強度差が認められ, $550 \mathrm{~nm}$ 付近で最大で一 定の $\Delta F$ を示すので, 定量操作として両溶液の励起波長 $474 \mathrm{~nm}$, 蛍光波長 $550 \mathrm{~nm}$ における $\Delta F$ を測定することに した.

\section{$3 \cdot 5$ 検量線の作成}

$2 \cdot 3$ の標準定量操作に従って 5-HT の検量線を作成した ところ，0.05〜2.5 $\mu \mathrm{g} / \mathrm{mL} の 5-H T$ 濃度範囲において, $y=102.5 x$ と原点を通る良好な直線を得ることができた. また決定係数は $R^{2}=0.999$, 相対標準偏差 (RSD) は $(n=5$, $1.0 \mu \mathrm{g} / \mathrm{mL} 5-\mathrm{HT}) 2.4 \%$ であり, 相関性及び再現性にも優 れていた.

3・6 5-HT 関連化合物の加熱前後の最大励起波長と最 大蛍光波長の変化

プロピレングリコール中, 種々の生理活性アミンや関連 物質の加熱前, 及び $170{ }^{\circ} \mathrm{C} 40$ 分加熱した後の最大励起波 長と最大蛍光波長を比較検討したところ, 5-HT と, その前 駆物質である 5-ヒドロキシトリプトファン（5-HTP）にお いて, 加熱後, 最大励起波長と最大蛍光波長ともに大きな 長波長シフトが見られたが, 他のアミン及び関連化合物に おいてはこのような現象はほとんど見られず，5-HT及び 5-HTP みが特異な蛍光挙動を示すことを認めた (Table 2). また他の化合物においてもプロピレングリコー ルとの加熱反応前後において最大励起波長と最大蛍光波長 に著しい相違が見られるので，これら化合物あるいは代謝 物の分別定量が可能と考えられる. なお Fig. 4 に検討した アミンなどの構造を示す.
Table 2 Effect of heating

\begin{tabular}{|c|c|c|c|c|}
\hline \multirow[b]{2}{*}{ Amines } & \multicolumn{2}{|c|}{ Before heating } & \multicolumn{2}{|c|}{ After heating } \\
\hline & $\begin{array}{c}\mathrm{EX} \\
\max \\
(\mathrm{nm})\end{array}$ & $\begin{array}{l}\mathrm{EM} \\
\max \\
(\mathrm{nm})\end{array}$ & $\begin{array}{l}\mathrm{EX} \\
\max \\
(\mathrm{nm})\end{array}$ & $\begin{array}{c}\mathrm{EM} \\
\max \\
(\mathrm{nm})\end{array}$ \\
\hline 5-HT & 291 & 349 & 474 & 550 \\
\hline 5-НTP & 289 & 347 & 470 & 542 \\
\hline Tryptophan & 284 & 352 & 270 & 463 \\
\hline 5-HIAA & 290 & 349 & 287 & 347 \\
\hline 5-Hydroxy indole & 284 & 344 & 284 & 346 \\
\hline Tyrosine & 284 & 315 & 271 & 316 \\
\hline L-Dihydroxyphenylalanine & 289 & 328 & 273 & 395 \\
\hline Dopamine & 289 & 331 & 251 & 333 \\
\hline Noradrenaline & 287 & 328 & 252 & 448 \\
\hline Adrenaline & 288 & 329 & 270 & 516 \\
\hline
\end{tabular}<smiles>N[C@@H](CC1CNc2ccccc21)C(=O)O</smiles>

L-Tryptophan<smiles>Oc1ccc2[nH]ccc2c1</smiles>

5-Hydroxyindole<smiles>C=C(O)[C@H](N)Cc1ccc(O)cc1</smiles>

L-Tyrosine<smiles>C=C(O)[C@H](N)Cc1ccc(O)c(O)c1</smiles>

L-Dihydroxyphenylalanine (L-DOPA)<smiles>NCCc1ccc(O)cc1</smiles><smiles>NCC(O)c1ccc(O)cc1</smiles><smiles>CNCC(O)c1ccc(O)cc1</smiles>

Fig. 4 The structure of amines used

\section{$3 \cdot 7$ 標準定量操作時における種々のアミンの蛍光強度}

$2 \cdot 3$ の標準定量操作に従って種々のアミンの蛍光強度を 測定したところ，5-HT と同じ濃度の 5-HTP は 5-HT の 1/2 の $\Delta F$ が得られたが，その他のアミンでは 5-HT の 10 倍モ ル反応させても，顕著な蛍光性は見られなかった (Table 3).

\section{$3 \cdot 8$ 共存物質の影響}

本操作法における共存物質の影響をセロトニン 1.0 $\mu \mathrm{g} / \mathrm{mL}$ に対して, 共存物質を試料量の数倍〜 100 倍モルの 範囲で添加して検討した（Table 4)，塩化ナトリウム，塩 化カリウム, ヨウ化カリウム, 炭酸カリウム, 塩化アンモ ニウム, 塩化マグネシウム, 塩化覀鉛, 酢酸ナトリウムに ついては, 試料量の 100 倍モルでもほとんど妨害しなかっ た. ヨウ化ナトリウムや亜硝酸ナトリウムについては試料 量の 100 倍モルにおいて正の妨害が見られたが，それぞれ 試料量の 10 倍, 1 倍モルにおいてはほとんど妨害が見られ 
Table 3 Fluorescenece intensity of various amines and related compounds by the procedure

\begin{tabular}{lcrrr}
\hline \multirow{2}{*}{ Amines } & \multirow{2}{*}{$\begin{array}{c}\text { Concentration } \\
\text { of amines } \\
(\mu \mathrm{g} / \mathrm{mL})\end{array}$} & $\begin{array}{c}\text { Sample } \\
(\mathrm{S})\end{array}$ & $\begin{array}{c}\text { Blank } \\
\text { (B) }\end{array}$ & $\Delta F$ \\
\hline 5-HT & 1.0 & 114.7 & 0.1 & 114.6 \\
5-HTP & 1.0 & 46.7 & 2.0 & 44.7 \\
Tryptophan & 10.0 & 19.2 & 0.3 & 18.9 \\
5-HIAA & 10.0 & 1.9 & 0.3 & 1.6 \\
5-Hydroxy indole & 10.0 & 0.3 & 0.3 & 0.0 \\
Tyrosine & 10.0 & 1.2 & 0.3 & 0.9 \\
Dihydroxyphenylalanine & 10.0 & 18.5 & 0.3 & 18.2 \\
Dopamine & 10.0 & 13.4 & 0.3 & 13.1 \\
Noradrenaline & 10.0 & 2.7 & 0.3 & 2.4 \\
Adrenaline & 10.0 & 30.4 & 0.3 & 30.1 \\
\hline
\end{tabular}

a) RFI (Relative fluorescenece intensity). $\mathrm{Ex} 474 \mathrm{~nm}, \mathrm{Em}$ $550 \mathrm{~nm}$

Table 4 Effect of foreign substances

\begin{tabular}{lcc}
\hline \multicolumn{1}{c}{ Substance } & $\begin{array}{c}\text { molar ratio } \\
(\text { Sub/5-HT })\end{array}$ & Recovery $(\%)$ \\
\hline $\mathrm{NaCl}$ & 100 & 100.0 \\
$\mathrm{NaI}$ & 10 & 100.0 \\
$\mathrm{NaNO}_{2}$ & 10 & 122.8 \\
$\mathrm{KCl}$ & 100 & 100.0 \\
$\mathrm{KI}$ & 100 & 100.0 \\
$\mathrm{~K}_{2} \mathrm{CO}_{3}$ & 100 & 100.0 \\
$\mathrm{CH}_{3} \mathrm{COONa}$ & 100 & 100.0 \\
$\mathrm{MgCl}_{2}$ & 100 & 100.0 \\
$\mathrm{ZnCl}_{2}$ & 100 & 100.0 \\
$\mathrm{NH}_{4} \mathrm{Cl}$ & 100 & 100.0 \\
Ascorbic acid & 5.0 & 79.7 \\
Citric acid & 0.1 & 88.6 \\
Oxalic acid & 100 & 100.0 \\
Glucose & 100 & 100.0 \\
Fructose & 100 & 100.0 \\
Phenylalanine & 1.0 & 80.7 \\
Thiamine & 0.1 & 96.0 \\
Caffeine & 1.0 & 91.8 \\
Pyridoxine & 1.0 & 92.9 \\
Creatinine & 1.0 & 82.2 \\
Cysteine & 1.0 & 84.4 \\
5-Hydroxy indole & 10 & 107.2 \\
& &
\end{tabular}

5-HT $1.0 \mu \mathrm{g} / \mathrm{mL}$, Ex $474 \mathrm{~nm}$, Em $550 \mathrm{~nm}$

なかった. またグルコースやフルクトースなどの糖類は 5-HTの 100 倍モルでもほとんど妨害しなかった. しかし ながら, アスコルビン酸, クエン酸, フェニルアラニン, チアミン, カフェイン, ピリドキシン, クレアチニン, シ ステインなどでは少量の存在においても負の妨害が見られ た。また，5-HTの基本骨格である5-ヒドロキシインドー ルでは 10 倍モルでもあまり妨害しなかった。

\section{$3 \cdot 9$ 実試料適用への検討}

本法を実試料中の 5-HT 分析に応用するための予備的検 討として, その添加回収実験を行った。試料としてヤギ血
Table 5 Recovery test

\begin{tabular}{cc}
\hline Sample & Recovery (\%) \\
\hline Goat serum & 103.3 \\
Calf serum & 100.0 \\
Human urine & 100.0 \\
\hline
\end{tabular}

5-HT $1.0 \mu \mathrm{g} / \mathrm{mL}$, Ex 474 nm, Em $550 \mathrm{~nm}$

清, 仔ウシ血清, ヒト尿を選び, それぞれの試料 $10 \mathrm{~mL}$ を 凍結乾燥した後, $10 \mathrm{~mL}$ のメタノールに沈殿処理後, 上澄 み溶液を $0.1 \mathrm{~mL}$ ずつ Sample 及び Blank 溶液に添加した結 果, 添加回収率は Table 5 に示すように, ヤギ血清で $103.3 \%$, 仔ウシ血清, ヒト尿で $100.0 \%$ と良好な值が得 られた. 今後より詳細な実試料の検討を行う必要がある が，凍結乾燥後に反応溶液に溶解させる簡便な前処理によ り, 内在性セロトニンについても同様に測定できる可能性 が示唆された。

$$
4 \text { 結 語 }
$$

セロトニンをプロピレングリコール溶媒中で加熱すると き，発蛍光体が生成する反応を用い，5-HT の簡便で高感 度, 選択的な蛍光光度定量法を開発した. 本法は $0.05 \sim 2.5$ $\mu \mathrm{g} / \mathrm{mL}$ セロトニン濃度範囲において，原点を通る良好な 検量線が得られ, 決定係数 $R^{2}=0.999$, 相対標準偏差 RSD $=2.4 \%(n=5)$ と, 相関性及び再現性にも優れているこ とを認めた，本反応において，最大励起波長，最大蛍光波 長ともに, セロトニンの自然蛍光よりも著しく長波長シフ トした蛍光体が得られるのに対し，セロトニンの代謝物や 前駆体，他の生理活性アミンではこのような蛍光現象はほ とんど確認できないため, これらアミンの分離定量が可能 であると考えられる. また, 5-HTの実試料（ヤギ血清, 仔 ウシ血清, ヒト尿) 中での回収率はほほ $100 \%$ を示し非常 に好結果を得ることができた。

発蛍光体の詳細な構造については, 現在検討中である が，MS や NMRにより構造を検討したところ，2 分子のセ ロトニンと 1 分子のプロピレングリコールが蛍光生成反応 に関与している可能性が確認できた.

\section{文献}

1) D. Silver, W. G. Anlyan, R. W. Postlethwait, C. V. Morgan, C. E. Mengel : Ann. Surg., 161, 995 (1965).

2) L. P. Johnson, R. D. Sloop, J. E. Jesseph, H. N. Harkins : Ann. Surg., 156, 537 (1962).

3) J. M. Feldman, T. M. O'Dorisio : Am. J. Med., 1986 , 41.

4) 有田秀穂他：“日本医事新報 No.4453”, (2009), (日 本医事新報社).

5) グッドマン・ギルマン: “薬理書・第 10 版一薬物 治療の基礎と臨床一 (上巻)”, p. 341 (2003)，(廣川 書店)。 
6) 佐藤 進編：“新薬理学テキスト”, p. 354 (2004), (廣川書店)。

7) 今堀和友, 山川民夫監修: “生化学辞典 (第 3 版)”, p. 421 (1998), (東京化学同人).

8) T. Yoshitake, K. Fujino, J. Kehr, J. Ishida, H. Nohta,
M. Yamaguchi : Anal. Biochem., 312, 125 (2003).

9) T. Yoshitake, J. Kehr, S. Yoshitake, K. Fujino, H. Nohta, M. Yamaguchi : J. Chromatogr. B. Analyt. Technol. Biomed. Life Sci., 807, 177 (2004).

\title{
Simple and Highly Sensitive Fluorometric Determination of Serotonin Using Propylene Glycol
}

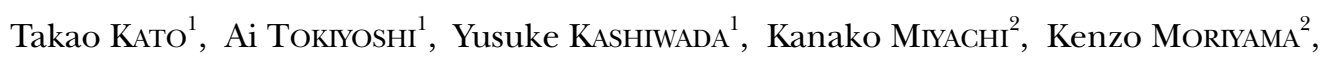 \\ Shigefumi MоRIмото ${ }^{3}$, Mamiko Asano ${ }^{1}$, Takako Yamaguchi ${ }^{1}$ and Yoshikazu Fujita ${ }^{1}$
}

${ }^{1}$ OsakaUniversity of Pharmaceutical Science, 4-20-1, Nasahara, Takatsuki-shi, Osaka 569-1094

${ }^{2}$ Department of Hospital Pharmacy School of Medicine, Kinki University, 377-2, Ohno-Higashi, Osaka-Sayamashi, Osaka 589-8511

${ }^{3}$ National Hospital Organization, Osaka Minami Medical Center, 2-1, Kidohigashi-machi, Kawachi-nagano-shi, Osaka 586-8521

(Received 18 March 2011, Accepted 17 June 2011)

A novel fluorophotometric method was established for the determination of serotonin on the heating in propylene glycol. In the determination of serotonin, the calibration curve exhibited linearity over a serotonin concentration range of $0.05 \sim 2.5 \mu \mathrm{g} / \mathrm{mL}$ at an emission wavelength of $550 \mathrm{~nm}$ with an excitation of $474 \mathrm{~nm}$; the relative standard deviation was of $2.4 \%$ ( $=5$ ) for $1.0 \mu \mathrm{g} / \mathrm{mL}$ of serotonin. The method was applied to recovery tests of serotonin in goat serum, calf serum, and human urine; the results were satisfactory. The proposed method should be useful for a simple and selective determination of serotonin in real samples.

Keywords : serotonin ; fluorophotometry; propylene glycol. 